\title{
Four-Fold Dimensionality in the Theoretical System of Cultural Construction of People's Livelihood-- Some Thoughts Based on Cultural Construction of People's Livelihood in Socialism With Chinese Characteristics
}

\author{
Li Kang ${ }^{1}$ and Zhaofei $\mathrm{Li}^{2}$ \\ ${ }^{1}$ School of Political Science and Public Management, Southwest University, Chongqing, China \\ ${ }^{2}$ Institute of Marxism, Southwest University, Chongqing, China
}

\begin{abstract}
As a means of livelihood at the cultural level, people's livelihood in terms of culture mainly refers to a kind of demand at the spiritual and cultural level after the problem of food and clothing is solved, such as, spiritual belief, ideological condition, cultural rights and quality of life, etc. With the cultural theory of socialism with Chinese characteristics being the guiding thought of cultural construction of people's livelihood, China has adhered to the path of cultural development of socialism with Chinese characteristics and has cultivated the high cultural selfconsciousness and cultural self-confidence of the people. Cultural construction of people's livelihood needs to adhere to the three basic principles of humanism, advancement and public welfare, ultimately realize the four basic goals, namely, cultural education to people, cultural intimacy to people, cultural benefaction to people and cultural enrichment to people, strength the cultural soft power of the country and construct a powerful socialist cultural nation.
\end{abstract}

Key Words: Cultural construction, people's livelihood, theoretical system, four-fold dimensionality

\section{Introduction}

At a new period of constructing a brand-new well-off society, the issue of people's livelihood in China has far gone beyond the demand at the level of material, but more importantly, the thirst for spiritual culture. Culture is the soul of people's livelihood. People's livelihood without culture is unhealthy and incomplete and is deficient of life vitality. The theoretical system of cultural aspect of people's livelihood with Chinese characteristics mainly has one guiding thought, two realistic requirements, three basic principles and four ultimate development goals. That is, to adhere to the cultural theory of socialism with Chinese characteristics as the guiding thought, the two realistic requirements of cultural selfconsciousness and cultural self-confidence, the three basic principles of humanism, advancement and public welfare and the four ultimate development goals of cultural education to people, cultural intimacy to people, cultural benefaction to people and cultural enrichment to people.

This paper is an achievement of 2012 Chongqing social sciences planning project "Study on Marxism Cultural Theory and Cultural Construction of People's Livelihood in Chongqing". Project Approval NO: 2012YBMK007

\section{One Guiding Thought: Cultural Theory of Socialism with Chinese Characteristics}

In the contemporary society, the function of culture becomes increasingly intensified and more and more becomes an important source for the national cohesion and an important component of the comprehensive national strength. As an advanced representative, the great socialist nation has positively constructed cultural livelihood of socialism with Chinese characteristics. This is helpful to consolidate the ruling status of the Communist Party of China and strengthen the centripetal force and cohesive force of the CPC; this is also helpful for the great development and prosperity of socialist culture, construction of a well-off society and fulfillment of the great rejuvenation of the Chinese nation. The socalled cultural livelihood with Chinese characteristics is to keep a foothold in the Chinese reality, comply with the principles of socialist cultural development, adhere to the guiding thought of Marxism, guide the public with the core value system of socialism, enrich the spiritual and cultural life of people with socialist cultural theory and enable the people to live with comfort, happiness, relaxation, joy and full of spirit and energy on the basis of being well fed, warmly dressed and well housed.

Cultural construction of people's livelihood in socialism with Chinese characteristics has to

Print ISSN 2329-0781 - Online ISSN 2329-079X / World Scholars http://www.worldscholars.org 
continuously "hold highly the great flag of socialism with Chinese characteristics, take as the guiding thoughts Marxism Leninism, Mao Zedong Thought, Deng Xiaoping Theory and the important thought of 'the three representatives', and deeply carry out the scientific outlook on development" . The primary task in construction of cultural livelihood of the people in socialism with Chinese characteristics is to adhere to the advancement direction of socialist culture and the fundamental idea is to be guided by the cultural theory of socialism with Chinese characteristics. "The theoretical system of socialism with Chinese characteristics is used to arm the brain, to guide in practice and to promote the work to ensure that cultural reform and development will go forward on a correct path" ${ }^{2}$. Then, it is likely to spring up the high tide of socialist cultural construction, build a powerful nation of socialist culture and realize the great development and great prosperity of socialist culture.

\section{Two Realistic Requirements: Cultural Self- consciousness and Cultural Self-confidence}

The primary task in construction of a powerful socialist cultural nation is to cultivate high cultural self-consciousness and cultural self-confidence. Cultural self-consciousness refers to cultural consciousness and cultural awakening and to the profound comprehension and mastery of people in the national culture. Cultural self-confidence refers to the firm confidence in the local culture. The former is the basis and premise of the latter, whereas the latter is the manifestation and extension of the former. The two interrelate, interact and promote mutually. These two, together, constitute the two basic realistic requirements in cultural construction of people's livelihood in socialism with Chinese characteristics.

\section{Cultural self-consciousness}

As the consciousness and awakening of people in terms of culture, cultural self-consciousness is mainly embodied in two aspects. The first aspect is that people have profound and rational comprehension and self-knowledge in the national culture and make frequent self-reflection and self-knowledge. After continuous negation of negation, they make development innovation and realize both qualitative and quantitative spiral escalation inter-conversion. The second aspect is that people learn to make a comparative reference to ancient culture and foreign culture, play their initiative to take in the rational elements to be used and pioneer a new state of cultural development. Cultural construction of people's livelihood in socialism with Chinese characteristics has to make the Chinese nation have habitual cultural self-consciousness, face up with all kinds of cultures at all times and in all over the world with a more reasonable, open and tolerable mind and absorb the quintessence for use.

\section{Cultural self-confidence}

Cultural self-confidence is relative to cultural inferiority and cultural self-conceit, a kind of scientific and rational cultural evaluation attitude, and is affirmation of the cultural value and firm confidence in cultural vitality. At present, lack of confidence in the national culture is mainly manifested as the great possibility to go to extremes and swinging between the two extremes of cultural inferiority and cultural self-conceit. At the very beginning of the reform and opening up, under the influences of western capitalism ideas, a fashion of worshipping foreign elements and fawning on foreign countries came into vogue in China. As a result, the national people depreciated the local culture. By contrast, quite a lot of viewpoints on cultural revivalism emerged and laid excessive emphasis on importance of the traditional culture but ignored modern culture. In the final analysis, the major reason for lack of confidence is the inaccurate positioning of the local culture and the failure to form the habit of cultural self-consciousness. Construction of cultural livelihood of the people in socialism with Chinese characteristics needs to have the cultural self-consciousness of the whole nation, and more needs cultural self-confidence to stimulate cultural self-improvement. In this way, a healthy and positive culture with the characteristics of the nation can be formed, which will finally improve the spiritual and cultural life of the vast majority of the public masses, enhance the cultural soft power of the country and form cultural self-confidence of the whole Chinese nation.

\section{Three Basic Principles: Humanism, Advancement and Public Welfare}

Construction of cultural livelihood of the people in socialism with Chinese characteristics needs to embody the essential features of socialism, and furthermore, needs to reflect the features of socialism with Chinese characteristics. It should have essential distinctions from cultural construction of western capitalism and reflect the superiority and advancement of the socialist system. In the meantime, compared with construction of cultural livelihood of the people 
in other socialist countries, it needs to reflect reality and characteristics of China and comply with the objective requirements for social development. Therefore, construction of cultural livelihood of the people in socialism with Chinese characteristics has to adhere to the following three principles.

\section{The principle of humanism}

The principle of humanism is a landmark principle in construction of cultural livelihood of the people in socialism with Chinese characteristics. It embodies the essence and superiority of socialism and exercises the scientific outlook on development with the core of human orientation. Adherence of cultural construction of the people's livelihood in socialism with Chinese characteristics to the principle of humanism is to enable the people to be the master and ultimate beneficiary of cultural construction and to reflect the master position of people. Cultural construction of the people's livelihood in socialism should, at all time, adhere to the basic policy of serving the people and the basic direction of serving the socialism, show respect for the people, come to understand the people, show care for the people, realize freedom and comprehensive development of the people and take the initiative in constructing a popular culture beneficial to the people.

\section{The Principle of Advancement}

Construction of the cultural livelihood of the people in socialism with Chinese characteristics has to adhere to the advancement direction of advanced culture of socialism and to unification of inheritance and innovation and give full play to the guiding function of advanced culture of socialism. According to Marxism, capitalism was the last class society in the process of human social development, while socialist society would be a brand-new social pattern that pioneered the history, which represented the most advanced social productivity and most advanced social culture. In order to make construction of cultural livelihood of the people in socialism, it is necessary to adhere to the principle of advancement. This is the manifestation of the essence of socialism at the level of culture and is the outstanding feature that distinguishes socialism from laggard culture in all other class societies.

\section{The principle of public welfare}

According to the historical materialism, the populace is the master and creator of the history. Therefore, we have to believe in the populace and rely on the populace and give full play to the initiative and creativity of the populace. In the process of construction of cultural livelihood of the people, necessarily, the populace occupies a position of subjectivity. The essence of socialism and the tenet of the $\mathrm{CPC}$ require us to serve the people wholeheartedly. When embodied in terms of culture, it is to guarantee the cultural rights of the populace and let the populace share the achievement of cultural development. This purpose determines that the greatest hallmark of construction of cultural livelihood of the people in socialism with Chinese characteristics is the public welfare and service. This requires us to adhere to the principle of public welfare in the process of the construction, construct a public cultural service system and meet with the basic cultural appeal of the vast majority of the public masses.

\section{Four Ultimate Goals: Cultural Education to People, Cultural Intimacy to People, Cultural Benefaction to People, and Cultural Enrichment to People}

The ultimate goal of cultural construction of people's livelihood in socialism with Chinese characteristics is to enable the people to share the achievement of cultural development, give full play to the leading role and guiding role of advanced socialist culture, continuously innovate socialist culture, gradually realize cultural education to people and cultural intimacy to people in the process of practical creation and finally attain cultural benefaction to people and cultural enrichment to people. It is necessary for the new socialist China to, first of all, realize evolution from "powerful nation" to "enrichment of people". Then, it is possible to jump over the bound between material and spirit, realize enhancement from material abundance to spiritual abundance and strengthen the centripetal force and cohesive force of the entire Chinese nation. Finally, both material and spirit harvest will be fulfilled, a well-off society will be built and the China dream of great rejuvenation of the Chinese nation will be achieved.

\section{Cultural education to people}

Cultural education to people is the premise factor in the ultimate objective system of cultural construction of people's livelihood. "It is necessary to arm the people with a scientific theory, to guide the people with a correct public opinion, to shape the people with lofty spirit, to encourage the people with excellent works and to form upward and positive spiritual pursuit and healthy and civilized life style in the whole society". 3 As the soul of people's livelihood, culture is an important reflection of the spiritual demand of people. An advanced socialist culture is able to stimulate the vast majority of the public masses to devote themselves to the career of 
socialist modernization construction in a full spiritual state, upward and positive life attitude and firm ideal and belief, fully play their enthusiasm and creativity to create more material and spiritual wealth and play more roles in building a well-off society and finally fulfilling the China dream of the great rejuvenation of the Chinese nation. In cultural education, one of the objectives in cultural construction of the people's livelihood in socialism with Chinese characteristics is to give full play to the education function of culture and realize its role in educating.

\section{Cultural intimacy to people}

Cultural intimacy to people is a mode factor in the ultimate objective system in cultural construction of the people's livelihood. As a demand factor in the spiritual and cultural aspect, culture should fully reflect the humanistic feelings and manifest its attractive force and influential power, which requires to continuously get close to the life reality of the public and to the ideological emotion of the public. "Humanistic feeling and love are the necessary condition to realize 'cultural livelihood of the people",. ${ }^{4}$ Cultural construction of the people's livelihood is supposed to warm the people, comfort the people, show care for the people, enable the people to feel infiltrated in a warm culture at any moment by means of setting up all kinds of convenient public cultural service facilities and to appreciate warmness and care, and move the people with emotion. Culture without emotion is boring, ruthless and wizened and is without any persuasive force or influential power. Cultural construction of the people's livelihood is supposed to benefit the people and bring convenience to the people, so as to attain getting close to the people and finally gain support of the people. Only cultural construction of people's livelihood that gains support of the people has a real meaning. In addition, cultural intimacy to people is also reflected in the fact that cultural construction of the people's livelihood should adhere to the policy route of closely interrelating the masses at any moment, understand the heartfelt wishes of the masses, satisfy the demands of the masses, protect the interests of the masses and share joys and sorrows of the masses. Cultural intimacy to the people and gaining support of the people are not only the objective of cultural construction of people's livelihood in socialism, but also the basic mode to fulfill the ultimate goal.

\section{Cultural benefaction to people}

Cultural benefaction is the core factor in the ultimate objective system of cultural construction of people's livelihood. The core of cultural construction of people's livelihood in socialism with Chinese characteristics is to let the vast majority of the public to really benefit and let the masses benefit generally. Cultural benefaction to the people is mainly reflected in two aspects. On one hand, in terms of spirit, cultural construction of the people's livelihood should benefit both the ideology and spirit of the masses. In this way, it is likely to edify the sentiment of people, relax both the body and mind of the people, moisten the soul of the people, direct their thought in a positive and upward direction and guide their spirit to step towards a healthy development path. On the other hand, in terms of material, the practical action in cultural construction of the people's livelihood helps to excavate potential of culture on the premise of changing the spiritual state and ideological condition of the vast majority of the masses, stimulate its positive role in serving modernization construction of socialism and transferring wealth at the spiritual level to the motive to create material wealth, which is exactly the initial manifestation form of cultural enrichment to people. Cultural benefaction to people is to ensure and continuously improve the efficacy of cultural construction of the people's livelihood. This should not remain on the form, but, instead, should grasp the essence through the form, put cultural construction of the people's livelihood practically into practice and let the vast majority of the masses practically appreciate the effect and benefit of culture.

\section{Cultural enrichment to people}

Cultural enrichment to people is a purpose factor in the ultimate objective system in cultural construction of people's livelihood. As the ultimate objective in cultural construction of the people's livelihood, cultural enrichment is the final embodiment of cultural education to people and cultural intimacy to people and is also the final sublimation of cultural benefaction to people. In the process of cultural enrichment to people, it is necessary to make qualitative sublimation, transfer spiritual motivation thoroughly into visible and touchable material wealth and form cultural productivity. This requires support and guidance of the CPC and the country, extensive participation of social enterprises and groups, and positive response of the people to form joint forces of cultural construction of the people's livelihood in which the whole society widely participates and make common efforts. Therefore, it is necessary to set up a public cultural facility system, cultural product supply system and public service security system, construct a healthy legal system, accelerate reform and innovation of cultural mechanism, depend on the market, finally establish market-oriented cultural industry, build a batch of supportive industries of national economy in terms of culture, 
strengthen the market competitive force of cultural industry and finally become regurgitation-feeding of benefiting the people, enriching the people and enhancing the material and cultural life of the people. Today when socialist market economy is developed rapidly, proposal and implementation of cultural construction of the people's livelihood is the necessity of history. Based on the reality cultural construction of the people's livelihood in socialism with Chinese characteristics, this paper summarizes the theory of cultural construction of people's livelihood in socialism and attempts to conclude a theory of cultural construction of people's livelihood that complies with the reality of China to serve the cultural construction of the people's livelihood in socialism with Chinese characteristics.

\section{Notes}

1. Outline of the Cultural Reform and Development Plan during the "12th Five Year Plan" Period, 2012.

2. Idem

3. Idem.

4. Zhang, Ke, \& Luan, Geping, Humanistic Concern and PeopleOriented Culture: On the Approaches of People-oriented Culture Construction. Hundred Schools in Arts, 2010(7).

\section{References}

Ao, Xiang. (2012). On the Definition and Functions in Cultural Livelihood of the People. Journal of Zhengzhou Institute of Aeronautical Industry Management, (3).

Fu, Bei, \& Wei, Huaiyuan. (2011). Cultural Livelihood of the People and Rebuilding of Marxism Belief. People's Tribune, (9).

He, Shizhong. (2011). Let People Share the Cultural Development Achievement --- Exploration and Thought of Chongqing City in Ensuring and Improving Cultural Livelihood of People. Seek Truth From Facts, (14).

Liu, Lianxiang. (2011). Thought on Cultural Livelihood of People. Scientific Socialism, (6).

Liu, Liquan, \& Xiao, Dongmei. (2012). On Interactive Correlation and Coordinated Development of Cultural Productivity, Cultural Soft Power and Cultural Livelihood of People. Marxism \& Reality, (1).

Wen, Zhaobiao. (2008). People's Cultural Livelihood: Let the Mainstream Ideology Approach the Populace. Journal of Huaiyin Teachers College (Social Sciences Edition), (3).

Zhang, Guozuo. (2011). Thought on implementation of the strategy of cultural powerful nation. Red Flag Manuscript, (21).

Zhang, Guozuo. (2012). Viewpoint on "the Great Development and Great Prosperity of Socialist Culture". Journal of China University of Mining \& Technology (Social Science), (1).

Zhang, Ke, \& Luan, Geping. (2010). Humanistic Concern and People-Oriented Culture: On the Approaches of Peopleoriented Culture Construction. Hundred Schools in Arts, (7).

Zhou, Bin. (2011). Make Cultural Livelihood of the People Strong with Great Development and Great Prosperity of Culture. Qunzhong, (12). 